\title{
Development Rights Transfer in New York City
}

When the Equitable Building in lower Manhattan was completed in 1915, its formidable bulk cast a shadow over seven acres ${ }^{1}$ and brought realtors and reformers together behind the nation's first comprehensive zoning ordinance. ${ }^{2}$ The tension between their conflicting desires-to encourage the intensive development of tax-generating property, and yet to limit urban congestion-has shaped the city's zoning ever since. ${ }^{3}$ Today the New York City Planning Commission is forging a new zoning tool, heated by the demand for office space and tempered by the recognition of the adverse consequences of unreasonably intensive land use. That tool is, in the parlance of planners, development rights transfer. ${ }^{4}$

"Development rights" is planning shorthand for the amount of floor area that may be developed on a given lot. Frequently, older buildings such as landmarks and townhouses do not fill the imaginary, three-dimensional envelope of space permitted by the zoning ordinance. These low-rise buildings are said to possess "authorized but unused" or "excess" development rights. By allowing the constructive "transfer" of these rights from smaller structures to the sites of new apartments or office towers, the Planning Commission intends both to preserve the landmarks and townhouses and promote the

1. At forty-two stories, the Equitable Building represented a thirty-five million dol. lar investment for its builder, General Thomas duPont. One hundred thousand people entered the building daily and thirteen thousand worked in its 1,250,000 squarc fect of rentable office space. The Equitable Building cut off the sunlight from the fronts of buildings as tall as twenty-one stories, and practically all of the sturrounding owners got reductions in their tax assessments when they proved a loss of rents duc to the light and air taken by their massive new neighbor. S. Tolt, ZoNed AMERICAN 71 (1969).

2. Woodbury, The Background and Prospects of Urban Redevelopment in the Unitcd States, in The Future of Cities aNd URBan Redevelolment 641 (C. W'oodbutry cd. 1959).

3. On the conflicting ends of the $1916 \mathrm{New}$ York Resolution, see S. ToLt, supra note 1 , at 184-85; for a similar conclusion regarding the 1961 Resolution sce S. MAKiELSK1, TutE Politics of Zoning 106 (1966).

4. The same device has been called "air rights transfer" by both reporters and lawyers. See, e.g., Burks, City Wants Air Rights to Hop, Skip, and Jump, N.Y. Timcs, April 26, 1970, \& 8, at 1, col. 1; Conti, Groups Fight to Stop Leveling of Landmarks by Urban Developers, Wall St. J., Aug. 10, 1970, at 1, col. 1; Marcus, Air Rights Transfers in New York City, 36 LAw \& ConTEMP. PROB. 372, 374 (1971). However, the technigue does not entail the transfer of "air rights."

The latter are a property interest in a three-dimensional location in space. Develop. ment rights, on the other hand, are simply a governmental license to build a de. fined amount of floor area as measured by the amount of lot area that has been constructively "transferred" to the project site.

Costonis, The Chicago Plan: Incentive Zoning and the Preservation of Urban Land. marks, 85 HARv. L. REv. 574, 592 n.58 (1972). 
construction of office buildings and luxury apartments, with their greater assessed valuation.

Theoretically, development rights transfer does not add to the overall congestion of a district: The new floor area permitted by the transfer has all been "authorized" by the area's original bulk regulations. This fiction conveniently ignores the fact that the rights transferred were hitherto "unused," and thus did not add to the district's needs for light, air, open space, transportation, and utilities. By encouraging the intensification of actual-as opposed to hypothetical-urban density, development rights transfer may well cast a new shadow over New York.

The use and potential abuse of this technique is of considerable import to other American cities. Just as the pioneering ordinance of 1916 had significant influence throughout the United States and was widely emulated, ${ }^{5}$ so also has New York's plan for development rights transfer in aid of landmark preservation already attracted national attention. ${ }^{6}$ It seems reasonable to expect that the Planning Commission's variations on the theme will also be emulated. A critical analysis now may avoid the making of the same zoning mistakes "over and over again ... because we do not have knowledge of what is applicable across-the-board and what is unique in each community."

\section{The Concept of Development Rights}

\section{A. Law and Order for Buildings: The 1916 Zoning Resolution}

To understand why development rights transfer may constitute a retreat rather than an advance in city planning, a brief review of zoning controls on building size is in order. The common law bequeathed to the American colonies two competing principles governing a landowner's right to build skyward. The better-known is

5. See E. Bassett, Zoning 8 (1940); H. JaMes, Land Planning in tuie UNited States for THE CITY, STATE, AND Nation 239 (1926).

6. On June 31,1971 , the U.S. Department of Housing and Urban Development announced that the National Trust for Historic Preservation had been commissioned to study the uses of the development rights transfer approach to save historic buildings. Professor John J. Costonis, the author of the article cited in note 4 supra, is the project director. Letter from Roger Holt, Assistant for Legal Services, Department of Ficld Sen: ices of the National Trust for Historic Preservation, to author, Jan. 26, 1972, on file at Yale Law Journal.

7. H. Perloff, A National Procram of Research in Housinc asd Urain RedevelopMENT ANd A Suggested Approach 20 (Washington, Resources for the Future, Inc., 1961). quoted in Sussna, Bulk Control and Zoning: The New York City Experience, 43 Lasd ECoNomics 158 (1967). 
the common law right to build upwards without legal limitation. Blackstone, elaborating on Coke, ${ }^{8}$ tied the ownership of the land surface to the ownership of the superjacent space:

Land hath also, in its legal signification, an indefinite extent, upwards as well as downwards. Cujus est solum, ejus est usque ad coelum (whoever has the land possesses all the space upwards to an indefinite extent), is the maxim of the law; upwards, therefore, no man may erect any building or the like to overhang another's land .... ${ }^{9}$

That this maxim was not absolute is demonstrated by the fact that the first reference to it in English case law is a note to a 1586 case, Bury v. Pope, ${ }^{10}$ a suit for "stopping another's lights." The Law of Ancient Lights gave a right of action to a landowner who was cut off from sunlight by the erection of a building on his neighbor's land, if the first landowner had uninterruptedly enjoyed that access for twenty years or more. ${ }^{11}$ However, this right to light has not fared well in competition with the right to build. The plaintiff in Bury v. Pope lost his suit, and the champions of light in the United States have been no more successful.

In 1838, in Parker \& Edgarton v. Foote,12 New York's highest court became the first state court to reject the right to light, ${ }^{13}$ noting that "it cannot be applied in the growing cities and villages of this country, without working the most mischievous consequences." 14 This frontier desire to improve newly-cleared land to the fullest was approved in the treatises of the "American Blackstone," James Kent. In his Commentaries on American Law (1826-1830), Chancellor

8. And lastly, the earth hath in law a great extent upwards, not only of watcr, as hath been said, but of ayre and all other things, even up to heaven; for cujus e'st solum ejus est usque ad coelum ....

Coke on Litrleton, Lib. 1, Ch. $1, \S 1$, at 42 (1628), quoted in R. Wright, THe LaW of AIRSPACE 16 n.20 (1968).

9. $2 \mathrm{~W}$. Blackstone, Commentaries *18. For a detailed history of the maxim, sec Klein, Cujus Est Solum Ejus Est. . . . Quousque Tandem?, 26 J. AIR L. \& Com. 237 (1959). For the subsequent development of the maxim in England, see R. WRIGitr, supra notc 8, at $11-13$.

10. Cro. Eliz. 118, 78 Eng. Rep. 375 (Ex. 1586). The court held that it was not a nuisance for a landowner to build a house which shut off the light of another whose housc had been erected thirty or forty years before, since it was the complaining landowner's "folly to build his house so near to the other's land." Id.

11. This doctrine, which is said to be the earliest attempt to assure a minimum standard of light to the ground story of all buildings, dates back to the reign of Richatrd Coeur de Lion in 1189. The practice of centuries was embodied in statute in the Prcscription Act, 2 \& 3 Wm. 4, c. 71 \$ 3, at 448 (1832). See G. FoRd, Building HElGit, BULK AND FORM 62 (1931).

12. 19 Wend. 309 (N.Y. 1838).

13. For collections of American cases on this point, sce 3 R. POWELL, THE LAW OF Real Property 485 (1970); 4 H. Tiffany, The Law of Real Property 556 (8d ed. 1989).

14. 19 Wend. at 318 . 
Kent cited Coke for the proposition that land "has an indefinite extent, upwards as well as downwards, so as to include every thing terrestrial, under or over it." 15

The extent of "upwards" could afford to be "indefinite" because the actual height of buildings, at least until 1860, was severely limited by the available technology. Without elevators, six stories was the limit of the most athletic tenants, and above the third floor rents decreased. ${ }^{16}$ Without steel frame construction, the thickness of masonry walls had to increase in direct proportion to their height. ${ }^{17}$

The development of steel skeleton construction ${ }^{18}$ and the invention of the elevator ${ }^{19}$ largely removed these constraints, ${ }^{20}$ yet the law offered no substitute. In 1865, New York was still a city of relatively low structures, four to five stories high..21 However, in 1870, when the first building to incorporate an elevator in its original design rose to seven stories, one of the top floors was soon leased at twice the rental of the city's best office accommodations. ${ }^{22}$ The lesson was not lost on New York's builders, who were to transform lower Manhattan from a horizontal to a vertical city in less than two generations. ${ }^{23}$

15. 3 J. Kent, Commentaries on American Law *401. On the acceptance of the maxim usque ad coelum in America, see R. WrIGHT, supra note 8, at 31-65.

16. E. Schultz \& W. Simmons, Offices in the SkY 19 (1959) [hereinafter cited as OFFICES].

17. S. Toll, supra note 1 , at $49-50$.

18. On the innovation known variously as the stecl-frame building cage, or skcleton construction, see S. Gredion, Stace, Time and Arcirtecture 204-08 (jth ed. 1967). Thr ten-story Home Insurance Company Building in Chicago, completed in 1885, was the first American steel-frame structure. OFFICEs, supra note 16, at 35.38.

19. Elisha Otis demonstrated the world's first safe elevator at the New York Crjstal Palace Exposition in 1853 . Otis would dramatize his new device's reliability by having himself pulled aloft, and then cutting the hoist rope: Quickly coming to a stop, he vould announce to the crowd, "All safe, gentlemenl" $S$. Toll, supra note 1 , at $47-48$. Nevertheless, it took developers several years to appreciate the possibilities of the clevator in commercial office buildings.

20. Other technical innovations also facilitated the rapid development of skyserapers. Edison's advances allowed electricity to be distributed to virtually crery street in Mianhattan, and by the time New York's first stecl-frame building was constructed, electric rather than gas illumination was the rule. Plate glass was mass produced by 1881 . Finally; one historian has suggested that the telephone was also vital to the growth of the skyscraper. See S. TorL, supra note 1 , at 51 .

21. Weisman, New York and the Problem of the First Shyscraper, J. Of TuE Soc'y of ArCH. Historians, Mar. 1953, at 15 .

22. This was the Equitable Building:

The history of this lower Manhattan building and its successor on the site brackets the beginning and end of the skyscraper's pre-zoning cra. By disclosing the possibility of elevators in office buildings, the first Equitable Building started the brealout from the traditional five-story maximum. The following Equitable Building carried the development of the skyscraper to such intolerable extremes that, bejond any other structure, it may be isolated as the one building which was a final cause of zoning law.

S. Tolx, supra note 1 , at 48 .

23. In 1894, the cross atop Trinity Church lost its title as the highest point in New: York, and the same year Harper's Weekly proclaimed "The Age of Skjscrapers." In 1896, 
Aesthetic considerations aside, there are three major reasons for building high: a need for concentration of certain functions in close association; a shortage of land; and simple prestige. ${ }^{24}$ On the southern tip of the island of Manhattan all three factors exist. Continued growth in the nation's trade and industry demanded the close proximity of brokers, bankers, lawyers, and corporate officers. ${ }^{20}$ Their demand for space has in turn doubled and tripled property values in the business center. ${ }^{26}$ Moreover, it was at least partly for the prestige of owning the largest commercial office building in the world that General duPont erected the infamous Equitable Build. ing, which helped provoke the passage of the first New York City Zoning Resolution. ${ }^{27}$

The 1916 Resolution was based on the conclusions and recommendations of the Heights of Buildings Commission, a body created by the Board of Estimate and Apportionment in $1913 .^{28}$ Their report

the words "sky line" were used for the first time. J. Kouwennoven, TuE Columuin Historical PORTRAIT of NEw YORK 394 (1953). For a list of the names and heights of New York's office towers through 1915, just prior to the passage of the city's first zoning ordinance, see OFFICES, supra note 16, at 64-72.

24. Gregory, Thoughts on the Architecture of High Buildings, in SyMrosıum oN THE Design of High Buildings 345 (S. Mackey ed. 1962). Cf. L. Sullivan, The Tall Officc Building Artistically Considered, in KINDERGARTEN CHATs AND OTHER WRITINGs 202 (1947).

25. By 1900, the port of New York was unloading nearly two-thirds of all American imports and sending on forty per cent of our exports. Because of the city's trade leader* ship, most banks kept reserve deposits there, and this accumulation of funds in turn made New York the security trading center of the nation. By 1900, sixty-nine of the country's 185 largest industrial combinations had their headquarters in the city. OFFICrs, supra note 16 , at $55-57$.

26. Id. at 57. Indeed, between 1875 and 1925 , land values increased so rapidly that it became economically prudent to demolish even fairly new buildings in order to lise the land more intensively. See Nelson, Appraisal of Air Rights, 23 Appraisal J. 495 (1955), cited in Costonis, supra note 4 , at 589 n.53. As city planner George Ford explained in his classic study:

As business increases, not in arithmetical proportion to population but according to a power of the increase in population, the intensity of business is greater in the larger cities. This causes a more rapid rise in land values of those cities and consequently quicker obsolescence of their office buildings.

G. FORD, supra note 11 , at 123-24.

27. On the construction of the second Equitable Building and the opposition to it, see C. Rodgers, New York Plans For The FuTURe 163.64 (1943); S. Toll, supra note 1, at 68-71; OFFICES, supra note 16, at 75-81. Besides the owners and tenants of office build. ings in the congested financial district, there were two other groups which supported a comprehensive zoning resolution. Urban reformers wanted to insurc adecuate light and air to the crowded tenements of the lower East Side. See Williams, The Evoltition of Zoning, 15 AM. J. OF EcoN. \& Soc. 253 (1956). And the merchants on Fifth Aventic, who had seen their business dwindle as the fashionable district was intundated by the garment workers from the lofts on the nearby side streets, hoped low height fimits would insure that their customers would not be disturbed by strange tongucs, dress, and odors. See S. ToLL, supra note 1 , at $158-59$.

28. New York City Heights of Buildincs Commission, Report to tue Commitree on the Height, Size and ARrangement of Buildings of the Board of Estimate and AiPORTIONMENT OF THE CITY OF NEW YORK (1913) [hereinafter cited as 1913 REloRT]. The purpose of the Commission was announced in the opening statement of the 1913 Reporl:

There is a growing sentiment in the community to the effect that the time has 
articulated the twin themes which have dominated planning policy in New York's central business districts to the present: the preservation of property values ${ }^{29}$ and the encouragement of office buildings. ${ }^{30}$ Control was to be maintained through height, ${ }^{31}$ setback, $^{32}$ and area limitations on building size. These regulations established what came to be called the "zoning envelope," an imaginary three-dimensional mold representing the maximum bulk to which a building might be developed under the proposed regulations. ${ }^{33}$ Significantly, nothing was said about specific limits on population density, nor about the relation of building size to the capacities of traffic arteries or mass transit services.

As enacted, the 1916 Resolution established five classes of height

come when effort should be made to regulate the height, size and arrangement of buildings erected within the limits of the City of New York; in order to arrest the seriously increasing evil of the shutting off of light and air from other building; and from the public streets, to prevent unwholesome and dangerous congestion both in living conditions and in street and transit traffic and to reduce the hazards of fire and peril to life....

Id. at $\mathbf{l}$.

On the 1913 Report, see S. Makielski, supra note 3, at 20-23; S. Toll, supra note 1, at $143-71$.

29. Height and court restrictions should be framed with a view to securing to cach district as much light, air, relief from congestion and safety from fire as is consistent with a proper regard for the most beneficial use of the land and as is practicable under existing conditions as to improvements and land valucs.

1913 REPORT, supra note 28, at 67. The Commissioners demonstrated so much concern for "safeguarding of existing and future investments and the encouragement of an ap. propriate and orderly building development," id. at 68, that protection of health and life became almost secondary.

30. Although the concern with office skyscrapers had brought the Commission into being, the 1913 Report revealed that not those buildings but department stores and hotels had the greatest average heights. Nevertheless,

the much greater proportion of high office buildings and their concentration in a

few areas make the determination of a maximum rule applicable to all buildings

very largely a question of determining what rule will be most appropriate for office buildings in the areas of maximum congestion.

1913 REPORT, supra note 28, at 17.

31. At this time New York was virtually without any direct controls over height, save for apartment and tenement houses which were held to one and 3 half times the width of the widest abutting street. However, Chicago, Baltimore, Washington, Boston and a number of other American cities had direct controls over building height by 1913. See S. Tour, supra note 1, at 155. The Supreme Court had reviewed Boston's height control regulations, holding that it was constitutional to enact such controls. Welch ": Swasey, 214 U.S. 91 (1909). A decade after the passage of the New York Resolution, the Court held that comprehensive zoning, going bejond mere height regulations, was also a constitutional exercise of the police power. Village of Euclid v. Ambler Realty, 272 U.S. 365 (1926).

32. Setback regulations require that a building, after rising from the strect or lot line a certain height, must be set back from that line at some fixed ratio, for example, one foot for each three feet of height. The setback regulation is responsible for the distinctive pyramid effect of buildings in downtown New York and other large cities.

33. George B. Ford, architect and secretary to the Commission (and later author of the leading study of building bulk regulations, see note 11 supra, carved soap models of the possible envelopes of skyscrapers in order to visualize their height and setback configurations. E. BASSET, AutoBIOGRAPHY 125 (1939), cited in S. ToL, supra note 1, at 165. 
districts, based on street width. ${ }^{34}$ Towers could rise to any height as long as they covered at their base not more than twenty-five per cent of the lot area and observed certain given setbacks from the streets. ${ }^{35}$ The 1916 Resolution also introduced a bonus provision, al. lowing a builder to add height if he provided open space beyond that required by the applicable district ordinance. ${ }^{36}$

Unfortunately, the planning philosophy of the Resolution was not as straightforward as its technique. "It is too big a city, the social and economic interests involved are too great to permit the continuance of the laissez faire methods of earlier days," the accompanying report proclaimed; but several pages later "economic interests" had triumphed over "social" ones: "No limit can be set to the growth and expansion of the city." 37

\section{B. Recidivism and Reform: The 1961 Zoning Resolution}

Within a decade planners were observing that the 1916 height and area regulations were inadequate..$^{38}$ Height zoning, while altering the form and indirectly limiting the bulk of skyscrapers, still permitted the crowding together of towering structures and encouraged separate buildings which overshadowed their districts. ${ }^{30}$

Between 1925 and 1931, Manhattan's office space increased by ninety-two per cent, and the next two years added yet another fiftysix per cent, including the Empire State Building and Rockefeller Center. The Grand Central area alone saw seventy new office buildings erected between 1921 and 1946.40 Belatedly, planners noted the

34. The height districts (designated as districts A through E) werc the "onc-times," "one-and-quarter-times," "one-and-half-times," "two-times," and "two-and-half-times" districts. Where the height map showed a "one-times" district, the height of a new build. ing could generally not be greater than one times the street width (which of course meant the actual width of the street). G. FORd, NEw YORK CiTY Building Zone Resolu. TION 6.15 (New York Title \& Mortgage Co. 1917), cited in Sussna, supra notc 7, at 158 n.10. The Commissioners' Plan of New York City of 1811, which established New York's grid. iron pattern, had provided for broad thoroughfares. That plan laid out a dozen north. south avenues, each 100 feet wide. Crossing these at right angles every 200 fect wcre 155 streets, each sixty feet wide, running east-west between the two rivers. See J. REI's, The Making of URBan America 296-99 (1965).

35. City OF NEw York, Building ZONE PlaN 19 (1916), cited in Sussna, supra notc 7, at $159 \mathrm{n} .11$.

36. The amount of prescribed open space for a lot became progressively greater in the five height districts $\mathrm{A}$ through $\mathrm{E}$. But if property owners in $\mathrm{C}$ and $\mathrm{D}$ districts set aside, in addition to other required open space, ten per cent of the lot area for the joint recreational space of the plot, they could build according to the requirements of $B$ and $C$ districts. Id. at 22-24, cited in Sussna, supra note 7, at 160 n.16.

37. New York City Commission on Building Districts and Restrigions, Final RePORT 9, 46 (Supp. ed., The City Club of N.Y. 1916).

38. Horowitz, Bassett on Density Zoning, Zoninc Dicesr, Aug. 1968, at 194, 195.

39. C. RodGers, supra note 27, at 168; S. Toll, supra note 1, at 204.

40. In the same period, only twenty new buildings rose in the former center of sky. scraper construction, the financial district, while eighteen new oncs were completed in the Times Square area. OFFices, supra note 16 , at 153. 
obvious: Subway traffic at express stops increased roughly in proportion to the increase in rentable floor space. As a solution, the nation's foremost expert on building height and setback regulations suggested in 1931 that "it might well be good business to provide the additional transit facilities as needed." 41

Belatedly, too, New York City's planners calculated the building capacity of the 1916 Resolution. They found that if the city were developed to the densities permitted by the zoning envelope, its residential districts alone would house seventy-seven million people; the commercial districts would embrace a working population of three hundred and forty-four million. ${ }^{42}$ Planning control was reasserted in 1944, when the height and area regulations of the more intensive districts were lowered to those in effect for the next most restrictive district. But the Planning Commission did not depart from the basic mechanics of the original Resolution and continued to regulate building size through height, setback, and area restrictions. ${ }^{\text {s }}$

As density controls, these techniques were indirect and inefficient. Students of New York's bulk zoning came to realize that height and setback restrictions were almost entirely devices to insure adequate light and air, which only incidentally limited the concentration of the working population. ${ }^{44}$ Admittedly, a city planner could determine the maximum building size allowable on each lot, translate this into square feet of floor space, divide that figure by an estimate

41. G. Ford, supra note 11 , at 46 .

42. Ackerman, Population Expectations, Zoning, Appraisals, and Debl, 49 AMEnicix CrTY, Oct. 1934, at 49, 50. During the Planning Commission campaign for the passage of the 1961 Zoning Resolution, the Commission chairman cited slightly smaller figures: "The city that our present zoning would permit is a nightmare of 55 million residents and 250 million workers." Felt, Preface to Voorhes, WALker, SMImi \& SMItm, Zosisc NEw YoRk CIrY at vi (1959) [hereinafter cited as ZoNinc NEw Yosk CmY]. The difference may be explained by changed assumptions on the nature of new development, family size, trends in floor space per worker and other such variables. While the com. parable residential figure under the 1961 Zoning Resolution is for a population of $10,900,000$, ZoNING NEW YORK CITY, supra, at 5 , the potential working population capacity of the central business district was not published, if indeed ever calculated. "In any event that issue is really academic since the problem is not what the theoretical capacity was or is, but rather some realistic approach to what legitimate needs are and how best to balance these." Letter from Edwin Friedman, Assistant District Director for Mctropolitan New York, State of New York Executive Department of Planning Services, to author, Feb. 25, 1972, on file at Yale Law Journal.

43. New York City Planning Commission, Retort on Amendients of tile Zoninc Resolution of The City of New York AfFectinc Heigit and ARea 16 (1914). The persistent use of the old tools of regulation is revealed by a comparison of zoning textbooks written before and after the 1944 amendments. See G. SMirh, THE LAW ANo Practice of ZoNING 458-60, 462-69 (1937); L. SQUIRE, ZONING IN NEW YORK 18, 31 (1948).

44. Williams, Deficiencies of Zoning Law and Legal Decisions, in AM. Soc'y of PLAs:Ning OfFicials, Planning 1950, at 164 (1951); Toll, Zoning for Amenities, 20 Law \& Cos:TEMP. Prob. 266 (1955); Vladeck, Large Scale Developments and One House Controls, 20 LAw \& ConteMp. Prob. 255 (1955); Note, Building Size, Shape and Placement Regu. lations: Bulk Control Zoning Reexamined, 60 YALE L.J. 506, 514-15 (1951). 
of floor space per employee, and arrive at the maximum working population of an area. ${ }^{45}$ But this is not an easily reversible computa. tion. One cannot use a desired density to generate an ideal height and setback configuration. Furthermore, the aim of all these calculations may be thwarted by a builder who lowers ceiling heights and thereby squeezes more stories into the permitted height of the building. ${ }^{40}$

Direct regulation of density was possible, however, through the Floor Area Ratio (FAR) technique. This ratio is an index figure which expresses the total allowable floor area of a building as a multiple of the area of its lot. ${ }^{47} \mathrm{~A} 10,000$ square foot lot, in a district where the FAR was twelve, would thus be limited to a maximum of 120,000 square feet of floor space. The latter figure is thus a constant control on the density of the lot. The builder can double the height of his building (provided he does not exceed the absolute height limitation of the district), but then can build on only half the lot, in order to stay within the maximum square footage of the FAR zoning envelope.

The FAR device had been incorporated into the zoning ordinance for the city's lowest density residential districts as early as 1940,48 but was bypassed in the general rezoning of 1944. Not until the Resolution of 1961, after seventeen years of political maneuvering and two major reports by architectural consultants, were FAR controls extended to the city's commercial areas. ${ }^{40}$ By that time, attention had turned from the need for FAR controls in the congested central business districts to the determination of their upper limits.

By fixing the maximum office floor space that can be erected in a city's downtown districts, FAR regulations limit the growth of business. Developers argued that setting the FAR too low would make it almost impossible to erect buildings big enough for the largest companies. The builders also complained that, because of the FAR limit, the taller the building erected, the smaller its floor plan will be, the less efficient office space it will provide, and the more space its elevators will use..$^{50}$

45. See Toll, supra note 44 , at 273.

46. ZoNing New YoRK CitY, supra note 42, at 49.

47. AM. Soc'y of Planning Officials, Floor AREa Ratio (Planning Advisory Scrvicc Report No. 111, 1958), provides a discussion of the device.

48. See Note, supra note 44, at 518 n.50. Four years later, the floor arca ratlo technique was described as "a comparatively recent concept." AM. PUb. HeALtu Ass'N, Planning the Neighborhood 40 (1948), cited in Toll, supra note 44, at 274 n.27. III 1955 one commentator observed that the floor area ratio regulation had, up to that time, appeared in but one case, decided in Ohio in 1925, in which there was dictum approval. Toll, supra note 44, at 274 n.27. The date of the case indicates the long dormancy of the technique.

49. S. MAKIELSK1, supra note 3, at 71-106.

50. See, e.g., OfFICES, supra note 16, at 280-81. Offices was written under the sponsorship of the National Association of Building Owners and Managers (now the Building 
Consultants hired in 1956 for the rezoning attempted to balance the builders' desires with the predictable needs of the city. The consultants took account of the size of the future national economy, New York's share of national office construction, future office employment, anticipated floor space per employee, and the amount of office space constructed since World War II. Their projections, extrapolated through 1975, indicated that there was likely to be an annual increase of about three million square feet of rentable space. Allowing for demolitions, more space per worker in existing buildings, and a somewhat higher vacancy rate, this amount of new construction would provide space for an additional 185,000 office workers by 1975.51

The amount of additional land needed to provide for this new office space naturally depended upon the FAR level. If the FAR were ten, 162 acres would be necessary, while a ratio of fifteen would permit the same intensity of development on 108 acres. The consultants' studies of post-World War II office buildings, erected under the old height and setback regulations, produced an average FAR of fifteen. Since developers had been building profitably at that level, and the 108 acres required to accommodate the projected increase in floor space at that level was "a modest amount relative to total commercial land available in the Central Business District" (Manhattan, south from 59th Street), the Planning Commission established fifteen as the FAR in its highest density commercial districts under the 1961 Resolution. 52

New York's builders and realtors objected strenuously to any reduction in bulk regulations in the new zoning ordinance. ${ }^{53}$ To win their support for the 1961 Resolution ${ }^{\text {th }}$ the planners incorporated two further features which undermined the limitation on building bulk represented by the FAR of fifteen. The first was a bonus device ${ }^{55}$

Owners and Managers Association International) in 1959, and was published just as the technique was gaining popularity among city planners. See Ax. SOC'Y OF PLANising OfficIALs, supra note 47.

51. ZoNING New YoRk Crry, supra note 42, at 10.11.

52. Id. at 11. For a compilation of the present FAR ccilings in the central business districts of fourteen other major American cities, see Am. Soc'y of Planning Officials, CBD Zoning Controls in Selected Cities (Planning Advisory Service Information Report No. 180, 1963). These ranged from a maximum FAR of 8 in Philadelphia to a maximum of 32.1 in Minneapolis. By contrast, the FAR ceiling in London's commercial districts is 4.5. Kahn, Real Estate With A British Accent, ReAL Estate Rev., Fall 1971, at 72, 73. 53. See S. MAKIELSKI, supra note 3, at 133-34, 137-38.

54. [T] The FAR limits were arrived at empirically, based on the fact that twothirds of post-war office construction took place at FAR's of less than 18, the maximum proposed under the 1961 legislation. The final numbers were to some extent arrived at pragmatically as a result of a consensus of interests within the City. Letter from Norman Marcus, General Counsel, New York City Planning Commission to author, Mar. 2, 1972, on file at Yale Law Journal.

55. For the initial use of the bonus device in New York City's zoning, see p. 344 sufra. 
which granted a developer a twenty per cent increase in permitted floor area in exchange for a plaza surrounding his building."0 $\mathrm{A}$ build. er might therefore increase his FAR from fifteen to eighteen simply by covering less of his lot and putting more of his permitted bulk into a tower.

The second innovation was a liberalization in the definition of the zoning lot to which the FAR figure was applied. The 1961 Resolution defines the term "zoning lot" to include not only the project site, but also any other parcel located within the same city block owned by the developer. For the purpose of this definition, ownership of all or part of a zoning lot includes control through a lease of at least seventy-five years. ${ }^{57}$ By leasing an adjacent underdeveloped or vacant parcel on a long-term basis and designating it as part of his total "zoning lot," a developer can add the authorized but unbuilt bulk of the leased parcel to the bulk of his project site.

The developers' enthusiastic adoption of this embryonic form of

56. "The slight increase in maximum permitted bulk resulting from this bonus is well justified by the benefits of increased open space." ZoNING NEw YORK CirY, supra note 42, at 127. Despite this explanation, other reasons for the FAR bonus wcre not aesthetic but political and economic. See note 54 supra. This twenty per cent floor area bonus provision has since proven to be "one of the most widely uscd features of New York City's 1961 zoning resolution." Barnett, Case Studies in Creative Urban Zoning, in The New Zoning: Legal, Administrative, and Economic Conceirr: AND Techniques 125, 127 (N. Marcus \& M. Groves eds. 1970) [hercinafter cited as Tue NEW ZONING].

57. The New York City Zoning Resolution defines the term "zoning lot" to include the following:

(c) A tract of land, located within a single block, which at the time of filing for a building permit... is designated by its owner or developer as a tract all of which is to be used, developed, or built upon as a unit under single ownership.

A zoning lot, therefore, may or may not coincide with a lot as shown on the official tax maps of the City of New York, or on any recorded subdivision plan or dced.

For the purposes of this definition, ownership of a zoning lot shall be decmed

to include a lease of not less than 50 years duration, with an option to rencw

such lease so as to provide a total lease of not less than 75 years duration.

NEW YORK, N.Y., ZONING RESOLUTION art. I, ch. 2, \$12.10 (1971).

Although the concept of the "zoning lot" was first explicitly introduced by the 1961 Zoning Resolution, there were attempts to utilize it in the prior Resolution. Without express authorization, however, the courts refused to accept it. Letter from Normall Marcus, note 54 supra. However, in 1972 the New York Court of Appeals gave its blessing to what General Counsel Marcus called the "contiguous lot assemblage siphoning principle," even where the parties to the lease cvidenced 110 cxpress in. tention to reach that result. In that case the defendant's lease of the plaintiff's property, executed in 1953, had a minimum term of twenty-one years with options to rencw for additional periods until the year 2052, and the defendant owned contiguous parcels in fee. The Court of Appeals held that he was entitled to full utilization of the leased parcel's development rights, absent a provision in the leasc precluding their transfer-despite the fact, unmentioned by the court, that such a transfer was not even possible until the adoption of the 1961 Zoning Resolution, cight ycars after the lease was signed. Newport Associates, Inc. v. Solow, 30 N.Y.2d 263, 392 N.Y.S.2d 617, 283 N.E.2d 600 (1972).

For examples of the "zoning lot" concept in other cities' ordinances, sec Culcsco, Ill., Municipal Code, ch. 194A, art. 3.2 (1970); Am. Soc'y of Planning Officials, Glossary of Zoning Definitions 12-13 (Planning Advisory Service Report No. 298, 1968). 
development rights transfer has been an important factor in prompting the city to adopt additional transfer provisions. To their use and abuse, this Note now turns.

\section{The Transfer of Development Rights}

In 1968, the Planning Commission enacted its first major development rights transfer regulation for a specific class of structures. This regulation (Section 74-79 of the zoning ordinance) was intended to supplement existing programs for landmark preservation, by permitting the owner of a landmark to transfer his authorized but unused floor area to adjacent parcels for development. ${ }^{.8}$

Landmarks were endangered both by the zoning ordinance's encouragement of new office buildings and by urban economics. Older buildings not only enhanced the city's character through their historic associations and architectural distinction; ${ }^{50}$ they also provided wells of light and air amid the skyscrapers. Yet their economic return could never approach that of the office towers which might replace them, so the urge to demolish was overwhelming. ${ }^{00}$

The intensive development of New York office space that began with the birth of the skyscraper in the late nineteenth century took its toll: In Manhattan today there is not a single building dating back to the seventeenth century and only nine going back to the eighteenth. ${ }^{61}$ In the twentieth century, successive waves of skyscraper construction were equally destructive of the city's architectural heritage. The office boom of the late $1950^{\prime} \mathrm{s}^{02}$ was particularly devastating. ${ }^{63}$ Although the New York Community Trust, a private organization, initiated a program of mounting bronze plaques on landmark struc-

58. New York City Planning Commission, Minutes 302 (May 1, 1968).

59. J. Pyke, Landalark Preservation 2-3 (Gitizens Union Research Foundation, Inc. 1970) [hereinafter cited as Landasark Preservation].

60. For example, the construction of Lincoln Center during the late 1950's made the venerable Carnegic Hall expendable, and its owners subsequently announced their intention to raze the historic Hall and replace it with a modern office tower. Given the economics of midtown Manhattan, the Hall's owners were undoubtedly correct in asserting that they could realize more income from a commercial building located on the same site. Only when area businessmen and landlords joined the chorus of protest, because they depended upon the continued presence of the Hall, was the building saved through purchase by a quasi-public corporation. LANDMsars: PreserviToN, supra note 59 , at 3.

61. Id. at 15 .

62. See Jacobs, New York's Office Boom, Archr. Forum, Mar. 19jï, at 104.

63. "The list of casualties included Pennsylvania Station, the Mistropolitan Opera House, and the Singer and Guaranty Trust buildings on lower Broadway and the Brokaw mansions. In addition, during this time at least two other landmarks, the Times Tower and the Black Starr building on Fifth Avenue, were transformed by the placement of contemporary facades over the old skeletons." LANDAsass: PreserviTION, supra note 59 , at 15 . 
tures, ${ }^{64}$ the preservation of such buildings was only the incidental result of a long-term tenancy or holdout owner.

In 1956, the state legislature had amended the General City Law to permit the acquisition or control of buildings having special aesthetic interest or value, ${ }^{65}$ but the city failed to act until pressured by citizens' preservation groups. ${ }^{60}$ In April 1965, the city council enacted the Landmarks Preservation Law, ${ }^{07}$ which created the Landmarks Preservation Commission. That Commission can designate any appropriate structure or site as a landmark; it can also name any area of the city possessing special historical, aesthetic, or architectural interest as an historic district. Both designations are made only after a public hearing, and must be approved by the city's Board of Estimate, a group composed of elected officials. ${ }^{68}$

The Commission is not required to consider the hardships landmark designation may impose on the owner of the building, even though he may not demolish it or alter its exterior without Commission approval. ${ }^{69}$ In practice, however, witnesses at the designation hearings do testify on the loss in property values expected from designation. ${ }^{70}$ After designation, the owner may appeal the Commission's refusal to grant permission for alteration or demolition only on the ground that he is not receiving a fair return from his landmark. ${ }^{11}$ The statute defines this reasonable return as a net annual return of six per cent of the assessed valuation of the building and its site. $^{72}$ If the landmark owner proves to the Commission's

64. Id.

65. See N.Y. Gen. City LAw § 20 (25-a), (McKinney 1968). The "Bard Law," named after its sponsor, Albert $S$. Bard, enabled the cities to adopt "[i]n any such instance such measures, [which] if adopted in the exercise of the police power, shall be rea. sonable and appropriate to the purpose, or if constituting a taking of private property shall provide for due compensation which may include the limitation or remission of taxes." Id. Such measures include provision for the "protection, enhancemcnt, perpetuation or use [of landmarks], which may include appropriate and reasonable control of the use or appearance of neighboring private property within public vicw, or both." Id.

66. Landmark Preservation, supra note 59, at 15 ; New York City Planning Com. Mission, PLAN FOR NEW YORK CITY, VOL. I: CRITICAL Issues 152 (1969) [hereinafter cited as Critical Issues].

67. 2 New York, N.Y., Charter and Administrative Code, ch. 8.a (1971).

68. For a description of the Landmarks Preservation Commission's powers and functions, see Wolf, The Landmark Problem in New York, 22 N.Y.U. INTRA. L. REV. 99 (1967). See also LANdmark Preservation, supra note 59, at 16-24.

69. See 2 New York, N.Y., Charter aNd Administrative Code ch. 8-a, § 207-5.0, a.(1) (1971).

70. See, e.g., Burks, Ozwners of Woolworth Building Call Landmark Law 'Onerous,' N.X. Times, Apr. 29, 1970, at 27, col. 3.

71. See 2 New York, N.Y., Charter and Administrative Code, ch. 8.a, $\$ \S 207-8.0$, a.(1)(2) (1971).

72. See id., $\S 207-1.0$, q. The statute provides that "net annual return" shall be the excess of earned income from the property over operating expenses, excluding mortgage interest, amortization, and allowances for obsolescence and reserves, but including a specified allowance for depreciation. 
satisfaction that he cannot realize this return without alteration or demolition, the Commission then works with him to devise a plan for preservation, which provides the required return. In devising such a plan, the Commission has the power, with the approval of the Board of Estimate, to grant partial or complete exemption from, or remission of, taxes. ${ }^{73}$

By mid-1969, some 285 structures had been designated as landmarks. ${ }^{74}$ Of this number, only one could not be saved from demolition. ${ }^{75}$ This overwhelmingly successful program of preservation has been achieved without resort to the tax relief possible under the preservation laws. ${ }^{76}$ Yet it was allegedly to supplement these tax abatement provisions that the Planning Commission enacted Section 74-79, allowing transfer of landmarks' unused development rights. 70 It should be recalled that the 1961 Resolution already permitted the transfer of potential development rights to a contiguous parcel, provided that both areas were under the same ownership in the same designated "zoning lot."78 But this meant that no merger would be possible where (1) all the sites contiguous to a landmark were already fully developed, (2) the neighboring buildings were themselves landmarks, or (3) the planners had elected to preserve a state of "underdevelopment" in the immediate vicinity of the landmark, as was the case with certain midblocks of brownstones. ${ }^{70}$ Moreover, the requirement that the lots be under common ownership imposed an additional barrier.

The 1968 amendment sought to remove these restrictions by broadening the definition of "contiguous" to include lots across the street or intersection from the landmark, and by permitting transfers between separately owned zoning lots. In the 1968 provision, however, the transferee lot was only permitted a twenty per cent increase in floor area through the transfer. The new law allowed a landmark owner to sell portions of his unused development rights to several adjacent owners, but he could not sell the same portion more than

73. Id., § 207-8.0, a.(2); see Landmark Preservation, supra note 59, at 19.

74. They included forty-three residences, eighty churches and related building5, sixty-nine public buildings, fifty industrial and commercial structures, seven cemeteries, one bridge, and one tree. Although these officially designated landmarks could be found in every borough and every kind of neighborhood, the majority were in Manhattan. Critical Issues, supra note 66, at 152.

75. Landakark Preservation, supta note 59, at 18-19.

76. See Costonis, supra note 4, at 592 n.60.

77. See note 58 supra.

78. See p. 348 supra.

79. Address by Norman Marcus, Counsel of the New York City Department of City Planning, at the First Conference on Legal Techniques in Preservation, Washing. ton, D.C., May 2, 1971, at 3. (Mimeo, copy on file at Yale Law Journal.) A modificd version of this address was later published. See Marcus, supra note 4. 
once. The development rights of the landmark's zoning lot were forever reduced by the amount of rights sold, and notice of the restrictions upon further development had to be filed in the appropriate land records office. Finally, approval of the transfer was conditioned upon a finding by the Planning Commission:

(a) that the permitted transfer of floor area or minor variations in the front, height and setback regulations will not unduly increase the bulk of any new development, density of population or intensity of use in any block, to the detriment of the occupants of buildings on the block or nearby blocks, and (b) that the [required] program for continuing maintenance will result in the preservation of the landmark. ${ }^{80}$

In its statement accompanying the rights transfer amendment, the Planning Commission cited the provision's "multiple benefits."

The owner of a designated landmark building can realize an economic gain by selling his unbuilt, but allowable, development rights; the buyer of these rights, in return, can acquire additional floor area he would otherwise not have; the neighborhood, meanwhile, can retain an essential amenity, a revitalized landmark, plus new development harmonious with the character of the area and of a quality unobtainable under previous conditions; the City, most importantly, can benefit by new tax revenues from what was previously untaxable. ${ }^{81}$

The Commission's concluding remark clearly identifies development rights transfer as primarily a method of fiscal ${ }^{82}$ rather than aesthetic zoning. It also suggests that the amendment would provide a good excuse for not utilizing the tax relief provisions originally enacted to compensate the landmark owner. ${ }^{83}$ But whatever its fiscal advan-

80. New YoRk, N.Y., Zoning Resolution, art. VII, ch. 4, $\$ 74.792$ (1971).

81. New York City Planning Commission, Minutes 303 (May 1, 1968). Prescrvation organizations greeted the transfer provisions enthusiastically. See, e.g., Gilbert, Saving landmarks: The Transfer of Development Rights, Historic Preservation, Jily.Scpt. 1970 , at 13 .

82. "Fiscal zoning" is any act which encourages developments adding more in property taxes than they cost in public services. In its usual context, the term refers to jurisdictions which seek industrial and commercial uses and luxury housing. See Narional Commission on Urban Problems, Building the American City 212 (1969). But it also embriccs ally practice which aims to produce tax revenues in excess of the cost of public services needed to encourage the development-and here, the only costs are the administrative expenses of the Planning Commission's approval of the development rights transfer, since the adequacy of public services in the area of transfer is not an explicit prerequisite for that approval. Former New York City Planning Commission member Beverly Spatt has publicly denounced development rights transfer as fiscal zoning. See Burks, Planners Seek to Shift Custom House Air Rights, N.Y. Times, Apr. 9, 1970, at 56, col. 4.

83. See p. 351 supra. 
tages, the new provision proved inadequate in dealing with the "Grand Central Terminal Crisis," 84 a plan to build a fifty-five story office building over the Terminal, a designated landmark, which would bring 12,000 more workers into the area. ${ }^{85}$

\section{A. Grand Central and Grander Transfers: The 1969 Amendment}

In the nineteenth century, the public outcry against the noise, smoke, and danger of the first trains had caused the city to move progressively northward the boundary below which locomotives could not run into Manhattan; thus, 42nd Street became the ultimate location of the present Grand Central Terminal. In 1875, a disastrous passenger train collision forced the New York Central Railroad to acquire several acres of valuable uptown property in order to widen its narrow tunnel. By 1902, the right-of-way had been redesigned and put underground to carry 600 trains a day. Above them, Park Avenue was carried on steel posts, as were nine cross streets similarly bridging the railyard. ${ }^{86}$

The cost of these improvements was met largely by the sale of air rights ${ }^{87}$ over the covered tracks to permit the building of commercial structures along Park Avenue. As hotels, clubs, apartment houses, and office buildings rose over the forty-eight-acre railyard, it became one immense realty holding under single ownership. Meanwhile, "Grand Central City" grew into the transportation transfer center of the metropolis, bound to the rest of New York not only by surface streets but also by the old elevated lines and the new subways constructed concurrently with the station. ${ }^{88}$

In this way, the common carrier became uncommonly wealthy. Its monumental and sumptuous Terminal, completed in 1913, cost $\$ 75$ million-\$225 million in today's dollars. ${ }^{80}$ In time, the value of the land occupied by the Terminal increased enormously, but the railroad business declined. This combination naturally led the New York

84. See address by Norman Marcus, supra note 79, at 6.

85. Fowler, Grand Central Tower Will Top Pan Am Building, X.Y. Times, June 20,1968 , at 1 , col. 4 .

86. Offices, supra note 16, at 52-54; Haskell, The Lost New York, Arch. Fonus, Nov. 1963, at 107 .

87. These were air rights in the classic sense of a property interest in a threcdimensional location in space. None of the buildings constructed on air rights leased or purchased from the New York (now Penn) Central receives ground rights from its legal possession of the air above the street level. These superimposed structures have no basements, and buy electricity, steam and hot water from the railroad. Trustces of Penn Central Transportation Company, Debtor, Proposed Sale of Mid-Manhattan Properties: General Memorandum 13-14, Aug. 11, 1971 (on file at Yale Law Joumal).

88. Haskell, supra note 86, at 109.

89. Id. 
Central to consider possible means of realizing at least some of the value of the terminal site. The Terminal represented a FAR of 1.5 in a district with a maximum FAR of eighteen. ${ }^{00}$ In September 1967, the New York Central first proposed to build a skyscraper containing some two million square feet of floor space over the Terminal waiting room; ${ }^{91}$ in January 1968, the new Penn Central leased that unused space to a private developer for fifty years at a minimum annual return of $\$ 3$ million.92 The erection of a building of such magnitude in an area which already suffered from extreme congestion made city planners shudder. But, given the generous FAR ceiling of the 1961 Resolution, the proposed building was completely within the zoning law and needed no variance or approval from the Planning Commission..$^{93}$

After more than a year of controversy and the presentation of two alternative plans by the architect, the Landmarks Preservation Commission finally blocked construction by ruling, in late 1968, that the proposed development had an exterior effect on the Terminal, which had been designated a landmark only one month before plans for the building had been announced. ${ }^{94}$ This ruling meant that the proposed building could not be erected without exhausting the Commission's various ameliorating procedures. ${ }^{95}$ The Penn Central's counsel had announced that the railroad would go to court to challenge the constitutionality of the landmarks legislation, ${ }^{96}$ and the negative ruling triggered a suit against the city for $\$ 8$ million a year until permission to build was granted. ${ }^{97}$

The Terminal presented a situation where a massive amount of development rights were available to be transferred in an area in which all the "adjacent" lots, as then defined, were already intensely

90. Shipler, Landmarks Zoning Change Proposed, N.Y. Times, Oct. 7, 1969, at 84, col. 4.

91. Fowler, Grand Central May Get A Tower, N.Y. Times, Sept. 21, 1967, at 1, col. 4.

92. Fowler, Breuer To Design Terminal Tower, N.Y. Times, Feb. 24, 1968, at 80, col. 3.

93. Huxtable, Architecture: Grotesquerie Astride A Palace, N.Y. Times, Junc 20, 1968, at 37 , col. 3 .

94. N.Y. Times, Aug. 7, 1967, at 31, col. 6.

95. Shipler, Landmarks Panel Bars Office Tower Over Grand Central, N.Y. TIncs, Aug. 27, 1969, at 1, col. 4. The Landmarks Preservation Commission's procedures after denial of a petition for alteration are described at pp. 350-51 supra.

96. Shipler, New Tower Sought For Grand Central, N.X. Times, Apr. 11, 1969, at 1 , col. 7.

97. The following press accounts provide a running history of the litigation: N.Y. Times, Sept. 5, 1969, at 40, col. 1; Tomasson, Penn Central Sues City in Fight to Build Grand Central Tower, N.Y. Times, Oct. 8, 1969, at 51, col. 2; Waggoner, Officials Called in Terminal Suit, N.Y. Times, May 21, 1972, at 17, col. 1; Waggoner, An Im. pressive Battery of Legal Talent Joins the Batte To Save Grand Central Terminal From Destruction, N.Y. Times, July 30, 1972, at 18, col. 1. 
developed. The 1968 amendment noted above was thus of no assistance in solving the Grand Central problem.

In reaction to the proposed tower, the Planning Commission moved in mid-1968 to acquire greater control over the construction in the immediate areas of the city's three major transportation centersGrand Central, Pennsylvania Station, and the Long Island Railroad complex in Queens. Within these districts, if established, the Commission would have the discretionary power to restrict the bulk of any new building to eighty per cent of the size otherwise permitted under the zoning law. The Commission members

made no secret of the fact that they consider the heavy development on the East Side of Manhattan in recent years to have overburdened the transportation facilities-rail, rapid transit, vehicular and pedestrian-in the vicinity of Grand Central.98

The plan could have rendered the Grand Central office tower project economically infeasible..$^{90}$ After public hearings, the proposal failed to gain the approval of the Commission and the Board of Estimate and was indefinitely tabled. ${ }^{100}$ How hard the planners fought

98. Fowler, Plan Board Seeks Wider Control of Rail Center, N.Y. Times, July 3 , 1968, at 70, col. 5. See also Bennett, City Urged to Bar Terminal Tou'er, N.I. Times, July 14, 1968, at 45 , col. 1 .

The almost total blockage of surface traffic movement in the central business districts, disregard of limited parking regulations, and cxcensirc double-parking have long been problems. In 1969 about 50,000 cars were towed off the streets. See Ascher, Welcome to New York, 36 PLANNing: A Newsletter of THE As. Soc'y of Planning Officiais 21, 24 (1970).

Before the publication of the master plan in 1969, one noted planner questioned the lack of realism in the 1961 Resolution with regard to vehicular traffic and off. street parking. Sussna, Parking and Zoning: A Case Study, 21 Trarric Q. $43 \overline{5}, 440$ (1967). Even Douglas L. Elliman, one of the city's major realtors, advocated heeping private automobiles out of Manhattan rather than encouraging any increase. N.Y. Times, Feb. 14, 1972, at 32, col. 5 .

Following Rome's adoption, in the spring of 1972, of a plan to eliminate masstransit fares and ban private motor vehicles from that city's center, spolsesmen for Mayor Lindsay said that while the idea was attractive, especially as a vay of discouraging the use of automobiles in New York, there was no source of financing for such an endeavor. The Lindsay administration has considered banning private motor vehicles from the city's center, and a few temporary pedestrian malls have been created on Madison Avenue and other thoroughfares. But the suggestion of a permanent ban has brought angry protests from merchants and businessmen, and no action has been taken. See N.Y. Times, April 1, 1972, at 27, col. 8.

99. See Fowler, supra note 98.

100. N.Y. Times, Nov. 28, 1968, at 36, col. 3. Ironically, the high FAR ceiling awarded the Grand Central Terminal area by the 1961 Resolution helped generate the cconomic threat to the landmark. The permitted FAR of the Terminal's zoning lot is cighteen, the Terminal itself being deemed a plaza which entitles the owner to a twenty per cent bonus above the regular district FAR ceiling of fifteen. See Shipler, supra note 90. Without those extra FAR rights, which had been added to the 1961 Resolution for political rather than planning reasons, see note 54 supra and accompanying text, the builder vould have been in the same position that the Planning Commission hoped to put him with its "special transportation center districts"-that is, unable to afford to erect atop the landmark an office building any smaller than the full FAR cighteen envelope riould permit. 
for their transportation district program is not clear, but they had proposed it only two months after enacting the first landmark development rights transfer provision. Having rubbed that genie out of the lamp, with all the promises of new construction permitted by transfer, it was certainly easier for the Commission to modify an expansive measure rather than to fight for a restrictive one.

The modification finally adopted by the Planning Commission, with one eye on enhancing its position in the Penn Central suit, ${ }^{101}$ was to amend Section 74-79. The amended transfer provision defined "adjacent" sites in the highest density commercial districts to include

a lot ... which is across a street and opposite to another lot or lots which except for the intervention of streets or street intersections form a series extending to the lot occupied by the landmark building. All such lots shall be in the same ownership. ${ }^{102}$

This amendment, announced October 7, 1969 (the same day the railroad's suit was filed), allowed the Penn Central to distribute the Terminal's "excess" development rights among the properties it controlled around the Terminal and up Park Avenue. One such prospective transferee lot was the Barclay Hotel on Lexington Avenue between 48th and 49th Streets, five blocks away from the Terminal. With this amendment, development rights could be not merely "siphoned off" to nearby parcels, but jumped over entire city blocks. ${ }^{103}$

The 1968 provision had limited development rights transfer to a twenty per cent increase in FAR on the transferee lot. Because the Terminal had such a great unused development rights potential, that limitation would have demanded several transferee redevelopments. Such widespread redevelopment in the densely-built district around the Terminal was hardly likely. For this reason the 1969 amendment revoked the twenty per cent restriction with regard to the highestdensity commercial districts (those with a FAR maximum of eighteen).

101. Shipler, supra note 90.

102. NEIV YORK, N.Y., ZONING RESOLUTION, art. VII, ch. 4, \$ 74.79 (1971). On "'ownership" of a zoning lot, see note 57 supra.

103. In his analysis of the New York plan of landmark development rights transfer, Professor Costonis criticizes the ordinance on the ground thit transfer can only take place between contiguous lots. Costonis, supra notc 4, at 586.87. But in this reading of the New York statute, Costonis seems to have missed the point that transfer over a greatly enlarged area-the keystone of his own "Chicago Plan"-was possible in New York more than two years before he published his own rights transfer proposal. Nor was Professor Costonis the first to suggest that development rights "hop, skip, and jump" from one lot to another some distance away. This was pro. posed by New York City Real Estate Commissioner Ira Duchan in April 1970. Sec Durks, supra note 4. 
The transfer of all of the unused development rights to one lot was thus permitted. As the Planning Commission's counsel later observed, this was a practical decision based on the railroad's eagerness to convert its development rights into revenue-producing office space as rapidly as possible. ${ }^{104}$

The Commission had one further rationale for lifting the twenty per cent restriction: the "prevalence of non-complying buildings [in excess of FAR eighteen] in the area," making "one more extra-large building ... relatively innocuous." 105 The planners must have been redefining "innocuous" as well as "adjacent lot": nothing else can explain the Commission's obliviousness to the transportation chaos which it was permitting through such a massive transfer of development rights. ${ }^{106}$

If the original rights transfer resolution could be characterized as fiscal zoning, ${ }^{107}$ this brief history reveals the 1969 amendment of that resolution to be a classic case of spot zoning: ${ }^{108}$ an amendment enacted solely for the benefit of one landowner which was not in accordance with a comprehensive plan. ${ }^{109}$ Permitting development rights

104. Marcus, supra note 4 , at 375 .

The Commission was ultimately more concerned with the realistic possibility that development rights would be transferred than with bowls of light and air when it amended the original development rights transfer sections to permit transfer across properties within a common chain of ownership.

Letter from Norman Marcus, supra note 54.

105. Marcus, supra note 4 , at 375 .

106. Before seeing any plans, the Planning Commission announced that, before clearing the project, it would have to be satisfied that the new tower vould not overwhelm the Grand Central district with more office vorkers than its transportation and services could sustain. Fowler, supra note 91. The concern was justified, if later effectively abandoned. In the Grand Central area, 80,000 people emerge from the concrete between 8:00 and 9:00 A.M.; and 200,000 surface in the course of a day. Huxtable, Slab City Marches On, N.Y. Times, Mar. 3, 1968, § 2, at 22, col. 1. Thic Penn Central's new skyscraper would have brought another 12,000 people into the area. Fowler, supra note 85 . Yet the same 12,000 would be overloading the same area even if the Terminal's development rights were dispersed among sereral railroadowned lots or transferred in one great block under the amended provision for transfer.

The Commission knew the extent of this strain. In its Plan for New Yorls City, the master planners noted:

The last major improvement in the subway system was completed in 1935. The subways are dirty and noisy. Many local lines operate well beneath apacity: but many express lines are strained way beyond capacity-in particular the lines to Manhattan, now overloaded by 39,000 passengers during peak hours.

CRrrical Isstues, supra note 66, at 48. The Lexington Avenue express-the only subway line serving the area in which the Terminal development rights would be transferredcarries 170 persons per car during the rush hour. Id.

107. See p. 352 supra.

108. See R. Anderson, Zoning Law and Practice in New York State, \$ 5.03, at 85 (1963); Comment, Spot Zoning and the Comprehensive Plan, 10 Sricicuse L. REv. 303 (1959).

109. The Plan For New York City did not consider permitting development rights transfers of the magnitude permitted by the 1969 amendment to Section $74-79$, even though the "Grand Central dilemma" is briefly discussed. Carticst Issues, supra note 66 , at 152 . 
transfer of such magnitude from the Terminal to a single transferec lot, given the appalling state of transit facilities in the Grand Central area, is the very antithesis of rational planning. Under the statute, that single transferee lot could have a FAR of $34.5,{ }^{110}$ almost twice the current permissible maximum. Fortunately for those who work or travel in the district, none of the Terminal's development rights have as yet been transferred.111 If it does happen, the owners of buildings to be overshadowed by the transferee project might well have the legal opportunity, on a spot zoning theory, to cut their new neighbor down to size. ${ }^{112}$

\section{B. Public Landmarks and Private Levies: The 1970 Amendment}

Although roughly one-quarter of New York's designated landmarks were publicly-owned ${ }^{113}$ when the original rights transfer amendment was adopted, that provision applied only to privately-owned land. marks. Transfers from publicly-owned landmarks, however, could conceivably be made under the 1961 Resolution's definition of "zoning lot" if the landmark site was contiguous to the developer's parcel and

110. This figure is reached by adding the eighteen FAR, permitted under the district limit, to the three FAR (twenty per cent) bonus for providing a plaza and the 16.5 FAR transferred from Grand Central Terminal.

111. After filing its suit against the city, see p. 354 supra, the l'onn Contral went bankrupt. On June 2, 1971, the bankruptcy trustees offered for salc virtually all of the railroad's mid-Manhattan property. See Bedingfield, Pennsy Will Sell 23 Valuable Sites in Mid-Manhattan, N.Y. Times, June 3, 1971, at 1, col. 8.

The only bid on the Terminal's development rights was made by the current lessee of the air rights, UGP Properties, Inc. UGP made package bids for cithur the Roosevelt Hotel or the Biltmore Hotel along with the Terminal development rights in order to bring itself under the language of the landmark development rights transfer provision and add to the maximum floor area permitted on the lot cleared by the demolition of either hotel. The bankruptcy trustces, who had vowed they would not sell the properties at "fire sale prices," rejected these bids: However fair the bids for the hotels standing alone, UGP had offered only \$3.5 million for the fee to the development rights which they were leasing for $\$ 3$ million a year for the next half-century. Wall St. J., Oct. 18, 1971, at 6, col. 2; id., Nov. 16, 1971, at 11, col. 1. Although the trustees have since recommended the rejection of ninc uncxpircd lases of its mid-Manhattan properties, the UGP lease on the Grand Central air rights was not among them. Id., Jan. 17, 1972, at 14, col. 2.

112. New York's planners have at least acknowledged this legal problem, although not in the Grand Central Terminal context and not explicitly in terms of the spot zoning objection. In his address to the National Trust for Historic Preservation, Norman Marcus asked rhetorically:

Over how many blocks can the benefit of a preserved landmark be rationalized? Does, for example, the property owner on East End Avenue buried in the shade of an overbulk new apartment house benefit from the preservation of a landmark on Fifth Avenue over a mile away?

Address by Norman Marcus, supra note 79, at 13. See also Marcus, supra notc 4, at 378.

Professor Costonis has attempted to construct a legal foundation for transfer of develop. ment rights over a wide area. See Costonis, supra note 4, at 620-31. There have, however, been no legal tests of the development rights transfer amendments and proposals dis. cussed in this Note, since none have been transferred. See pp. 367.68 infra. The aim of this study is not to decide the legality of development rights transfer, but rather to question its utility as a preservation method and its rationality as a zoning device in central business districts which are already heavily congested.

113. CrITICAI Issues, supra note 66, at 152. 
was under his "control."11* In fact, the first transfer of development rights from a public landmark used this provision.

In the fall of 1969, an owner of land adjacent to the Appellate Division Courthouse, a city-owned landmark with Corinthian columns and rooftop statuary, proposed to construct an office tower containing approximately a half million square feet; applicable FAR limitations for the district permitted the construction of only 400,000 square feet. To aid the builder, the city took advantage of its power to lease municipally-owned buildings for up to ninety-nine years. ${ }^{115}$ The developer leased the courthouse for fifty years with a twenty-five-year renewal option; he then subleased it back to the city, reserving the one hundred thousand square feet of floor area he needed for his office project. Since the developer now had a lease for seventy-five years, he was deemed to be the owner of the courthouse lot and could combine it with his own to produce more floor space under the district's FAR. ${ }^{116}$ The city's gain averaged $\$ 46,000$ per annum-a total for the lease term of $\$ 3,450,000.117$ None of this was marked for maintenance of the courthouse or improvement of the transit systems serving the huge new office building. Not long thereafter, the Planning Commission amended Section 74-79 to bring publicly-owned landmarks under its provisions. This 1970 amendment requires a finding by the Commission,

$[t]$ hat in the case of landmark sites owned by the City, State or Federal Government, transfer of development rights shall be contingent upon provision by the applicant of a major improvement of the public pedestrian circulation or transportation system in the area. ${ }^{118}$

114. See p. 348 supra.

115. 1 NEw York, N.Y., Charter ANd ADministrative Code, ch. 15, $\$ 384(\mathrm{~b})$ (1963).

116. As quoted in Sher, "Air Rights" Lease, Zoning, N.Y.L.J., Oct. 9, 1970, at I. the operative clause of the lease provides:

Section 401.(a) Tenant is hereby given the right, prior to or during the Demised Term, to combine the zoning lot of the Demised Premises, with the zoning lot of the Adjoining Premises, so as to obtain a combined Floor Area Ratio (as defined in the Zoning Resolutions and the Laws of the City of New York) for the zoning lots of the Demised Premises and the Adjoining Premises; however, as a result of such combination of zoning lots, Tenant shall not obtain more than one hundred thousand $(100,000)$ square feet of floor area from the zoning lot of the Demised Premises.

117. The rent would be $\$ 35,000$ a year for the first twenty years, and $\$ 50,000$ for the remaining fifty-five years, or $\$ 3.50$ and $\$ 5.00$ a year per square foot of ground area, respectively. According to Real Estate Commissioner Ira Duchan, who supervised the transaction, office rents in that area at the time of transfer were approximately $\$ 7.00$ and higher, and based on these figures, the developer would need to increase his tenants' rents for 520,000 square feet of office space by less than seren cents per square foot for the first twenty years, and less than ten cents per square foot for the last fifty-five years, to cover his rental payments to the city for the privilege of adding 100,000 square feet to his structure. See Whether Hot or Cold . . Air Rights Loom Today, CrTY Trtue Ins. Co. Record, June 1970, at 1.

118. New YoRk, N.Y., ZoNING RESOLUTION, art. VII, ch. 4, § 74-792, 5.(c) (1971). 
Clearly, in the future, public benefits were to be extracted as the price of transfer by levying upon the private builder who would utilize the development rights. As the Commission's General Counsel later explained:

The additional requirement in the case of development rights transfers from public landmarks was an attempt to recognize the additional obligation borne by the public in supporting its own landmarks. Transfer of air rights over public landmarks must therefore accommodate the notion of the private transferee developer providing a major improvement in the public pedestrian circulation or transportation system in the area. Developments incorporating formerly publicly owned air rights are therefore held to a higher amenity standard than those utilizing privately owned and transferred air rights. Presumably this negates any thought that the city might sell air rights solely to bolster the municipal treasury. ${ }^{118}$

This admirable objective is, however, tarnished by the circumstances surrounding the amendment. The new provision was added, not as an abstract principle determined after deliberate consideration, but in response to one specific development project. The amendment was the product of a proposal involving the massive but squat United States Custom House, which faces Bowling Green at the foot of Broadway. Under the zoning regulations, the Custom House's permitted zoning envelope contains 1,134,000 square feet of floor space, of which only 344,200 square feet have been developed. The building's unused development rights, 789,800 square feet, represent a floor area roughly equal to that of the Woolworth Building. A neighboring developer wanted to replace his fifteen-story building with a new project, perhaps as high as fifty stories, using the Custom House's development rights. The Planning Commission obliged him by again amending Section 74-79.120 The Commission held that the 1970 amendment meant that in return for approval of the Custom House transfer, the builder had to make a substantial contribution to increasing the underground access and corridors to the adjacent Bowling Green subway station and to contribute to a fund for or take a direct part in preserving the Gustom House. ${ }^{121}$

119. Letter from Norman Marcus, supra note 54.

120. "The zoning law change was specifically carpentered to fit the building plan at No. 1 Broadway ..." Burks, supra note 4, at col. 2. See also Dissenting Report of Commissioner Beverly Moss Spatt, in 4 New York City Board of Estimate, Gencral Proceedings 3281-83 (1970). Other details of the Custom House development rights transfer are given in Burks, Planners Seek to Shift Custom House Air Rights, N.Y. Times, April 9, 1970, at 56, col. 4 .

121. See Burks, supra note 120. 
Whether the Commission might have won a "higher amenity standard"122 from the builder is now a moot question, for the transaction was never consummated. ${ }^{123}$ The provision, nevertheless, remains on the books as clear evidence of the Commission's engerness to accommodate potential developers. ${ }^{124}$

\section{The Battle of the Brownstones}

Although the original rights transfer provision had allowed transfer to "residential developments or enlargements,"12s all of the transfers actually contemplated or proposed through the fall of 1970 had involved only office buildings. But the provision recognized that new,

122. See p. 360 supra.

The planners' belated concern for the impact of development rights transfer on the transit system serving the area was well-founded. In the same year that the Com. mission hoped to approve the Custom House transaction, more than $14,000,000$ riders used the single, narrow platform of the Bowling Green subway station. Realistieally, no "higher amenity" could have been extracted from that single builder which would have countered the added strain of two thousand new workers arriving daily at that station. Dissenting Report of Commissioner Beverly Mloss Spatt, supra note 120, at 3282.

123. This occurred for the same reason that no other development rights transfers have been manifested in new office buildings, i.e., the weak narket for new office floor space in New York. See Strachen, The "Aforming After" In New York Is Today, REAL ESTATE REv., Fall 1971, at 46; Horsley, Office Leasing Piclure Dampens Building Plans, N.Y. Times, Feb. 6, 1972, § 8, at 1, col. 1; Oser, J'acancy Rate High in Midtoun Offices, id., July 9, 1972, $\$ 8$, at 1, col. 5; Brown, Rates of Occupancy in Office Structures Continue 2-Year Drop, Wall St. J., Aug. 16, 1972, at 1, col. 6.

124. The new amendment provoked a resounding dissent from planning Commis. sioner Beverly Moss Spatt, who said she did not believe the city should be "selling" zoning rights of public landmarks. Commissioner Spatt wrote:

This leasing is accomplished without referring the matter to the Planning Com-

mission and, in actuality, makes today's text change meaningless and superfluous.

Leasing and selling air rights in such an ad hoc manner is nothing but spot

zoning. It can only lead to an unplanned future-to chaos.

Dissenting Report of Commissioner Beverly Moss Spatt, supra note 120, at 3283.

In an interview during the hearings preceding the amendment's adoption, she asked, "If we sell the air rights over the Custom House the first time, what will be next? The Public Library on 42nd Street? And the museums?" Burks, supra note 120, at col. 7. A Commission spokesman said later that the development rights oter the Public Library might indeed be transferred in some future project. Mrs. Spatt. despite an energetic campaign, was not reappointed to the Commission when her ierm expired at the end of 1970. N.Y. Times, Jan. 1, 1971, at 32, col. 2.

The Custom House transfer proposal was a display of both bad planning and chutzpah. The federal government was and is the fee owner of the Custom House, and usually takes umbrage when the city designates a federal structure as a landmark which cannot be altered or enlarged. With the amendment of May 1970, which would have made the Custom House transfer possible, the Planning Commission seemed to propose bartering away development rights belonging to the federal government. The Executive Director of the Landmarks Preservation Commission "conceded a possible conflict of interest with the Federal Government in the Custom House case." Burks, supra note 4, at 9, col. 4 .

125. NEW YORK, N.Y., ZONING RESOLUTION, art. VII, ch. 4, $\$ 74-79$ (1971), reads in pertinent part:

[T] he City Planning Commission may permit development rights to be transferred to adjacent lots from lots occupied by landmark buildings . . . and may permit in the case of residential developments or enlargements, the minimum required open space or the minimum lot area per room to be reduced on the basis of such transfer of development rights ..... 
high-rise luxury apartments would also generate greater tax revenues and was designed to encourage them. Furthermore, no conceptual bar limited the applicability of development rights transfer to landmarks alone. Hundreds of older buildings failed to fill the FAR envelope permitted under the 1961 Zoning Resolution, and very few were designated landmarks.

It was therefore not surprising that in 1970 the Planning Commission formulated a zoning amendment which would have allowed builders of high-rise apartments to exceed their FAR restrictions by purchasing and utilizing the unused development rights of smaller townhouses. ${ }^{126}$

The proposal met determined opposition, however, and the Com. mission retreated. Six weeks after proposing the amendment, the Commission announced that it had decided to "either drop the item or continue the matter to a future hearing in order to reformulate it." 127 The full history of the proposal suggests that its abandonment was a rare example of a politically expedient decision that was also wise.

The upper East Side of Manhattan, for which the amendment was primarily designed, ${ }^{128}$ is bounded by the East River, Central Park, 59 th, and 96 th Streets. Its residential population $(200,200)^{120}$ roughly equals that of Austin, Texas. ${ }^{130}$ As the planners conceded, this area had seen the greatest concentration of private residential construction in the city, built upon some of the nation's most expensive real estate. ${ }^{131}$ To allow developers a return on their investments, the 1961 Resolution permitted a living density that would be the highest in the world: A builder can cover every square inch of the site in constructing up to 363 four-room apartments per acre. ${ }^{132}$

126. New York City Planning Commission, Rep. CP-21420, in Calendar of the City Planning Commission of the City of New York, Nov. 18, 1970, at 3.8.

127. Knowles, East Siders Claim High-Rise Victory, N.Y. Times, Jan. 1, 1971, at 1, col. 2, at 32, col. 5 .

128. The change would have applied along the whole East Sidc, as wcll as to a smaller area on the West Side abutting Central Park. See Knowles, supra note 127, at 1 , col. 2. That the fashionable upper East Side was the real target of the proposal may be deduced from the Commission's rezoning of fifteen tracts in that area to permit more high-density apartment projects just over a year after the development rights plan was defeated. See N.Y. Times, Feb. 13, 1972, at 50, col. 1.

129. N.Y. Times, Feb. 13, 1972, at 50, col. 1. The same area's population during the working week is 350,000. Testimony of William J. Diamond, Chairman of Man. hattan Community Board No. 8 on the Master Plan 1, Feb. 8 , 1972 (mimco, on filc at Yale Law Journal).

130. CRITICAL Issues, supra note 66 , at 115 .

131. Id. at 140. The land cost of Manhattan private high-rise construction has gone from a range of $\$ 30-\$ 70$ per square foot in 1960 to the range of $\$ 60-\$ 125$ per square foot in 1970. New York City Department of Citry Planning, Infill Zoning. 5 (1972) [hereinafter cited as INFILL Zoning].

132. CRITICAL IssUES, supra note 66, at 141. To understand what these high densities mean, one need only compare the population per square mile of the most densely 
Since the 1961 Resolution, such zoning (R-10) has been limited to the wide north-south avenues and major cross-town streets in Manhattan's luxury residential areas. In these areas, the authors of the official Plan for New York City in 1969 found that,

buildings of great bulk are tolerable. The high level of services and transportation access and the relative roominess of the apartments are compensation for the high degree of stacking. . . . To fill up whole neighborhoods with this kind of building, however, would clearly be wrong. The service load, for one thing, would be intolerable.

There would be neither space nor sense of space. Most of the buildings would be in perpetual shadow.

The creation of such luxury tenement districts would be an act of cannibalization. The smaller scale of the side streets is one of the major reasons why New York's most pleasant neighborhoods are pleasant-and why big towers on the avenues and corners can do as well as they do. The towers borrow space and sunlight from the lower buildings on the side streets. ${ }^{133}$

To preserve these midblock wells of light and air, the Planning Commission in 1961 had placed the side streets of the upper East Side under the protection of lower density zoning (R-8), permitting a maximum of only 247 apartments per acre. ${ }^{134}$

The Commission released its residential transfer amendment in November 1970. It proposed to permit the transfer of unused development rights from buildings in the midblock R-8 districts to R-10 lots fronting the avenue, where both the R- 8 and $R-10$ districts were located within the same city block. The amended provisions might also be applied to the transfer of development rights within a single zoning lot divided by a boundary between an R-8 district and an $\mathrm{R}-10$ district. The amendment borrowed the original percentage

zoned areas in Manhattan with that of selected high density districts in other major cities in the world: Manhattan, 71,145; Paris, 69,368; Tokjo, 63,800; Mexico City, 61,864; London, 34,315; Moscow, 30,400. The population per square mile of the entire city of New York is 25,452. Id. at 37. Higher population densities do exist. According to its latest census, Calcutta has a density of 102,000 per square mile. G. Mlooruouse, Cilctits 89 (1972).

133. Critrcal Issues, supra note 66, at 111 .

134. The Commission came under great pressurc to remap these areas to R-10 density: Builders claimed the prices of R-8 tracts were so high that only through rezoning could they be profitably developed. Critical Issues, supra note 66, at 20.21. In the 1969 master plan, the Commission correctly rejected this as a circular argument, even though it deplored the drop in construction of new apartments. Id. at 20-21, 141. Private housing construction of multiple dwelling units in Manhattan dropped from 5,837 in 1966 to 1,062 in 1970 , largely as the resule of the rise in the costs of construction and interest. INFILL ZoNiNG, supra note 131, at 5, 38. 
limitation of the 1968 transfer law: The builder of the high-rise might not exceed his FAR limit by more than twenty per cent.

The proposal also required that the transferee developer increase the amount of open plaza space on his site by as much as he increased the floor space of his building. Since apartment developers are not ordinarily required by the zoning ordinance to provide such open space for the public, this provision represented another ap. plication of the planners' long-standing policy to encourage open space by permitting buildings to exceed the otherwise applicable FAR limit. Another provision allowed an avenue developer to purchase any deteriorated side block property, raze it, and add the square footage to that of his avenue property, although this could be done only with the Commission's approval. As with the landmarks provision, transfers would be "irrevocable" and recorded, so that the transferred rights could no longer be developed on the transferor lot.130

The success of prior development rights transfer amendments hinged on two factors: the paucity of sites-all landmarks-which would be affected, and the absence of any organized constituency which would have to live with the results. In the battle of the brownstones, however, people who would have to contend with the increased density and building bulk resulting from development rights transfer on a scale never before proposed, had a voice. Their response to the planners was resoundingly negative. ${ }^{130}$

135. New York City Planning Commission, supra note 126.

136. Undaunted by its reversal, the Planning Commission later proposed to allow public institutions to increase their size by permitting development rights transfer from smaller, outlying buildings. The Commission argued that the proposed resolution would not alter the total density permitted an institution, but would permit grenter flexibility in its deployment. Once again Community Planning Board 8's Chairman, William Diamond, challenged the proposal on the grounds that it would remove light and air now available to nearby apartments. Van Gelder, Air Rights 1ssthe Pressed By Board, N.Y. Times, Sept. 19, 1971, at 54, col. 4. This scheme was then abandoned in favor of a proposed amendment which calls for the "updating of regulations pertaining to large-scale community facility developments, giving the [Clty Planning] Commission and the Board of Estimate the power to modify bulk regula. tions." Under the proposal, such institutions would not have to apply to the Board of Appeals and Standards in order to alter the size and location of new or existing construction. Goodman, Planners Vote to Ease Zoning Rules for Community III. stitutions in the City, N.Y. Times, April 6, 1972, at 39, col. 1. Thus, just as its develop. ment rights transfer plan for the mid-block brownstones was defeated by community opposition, the Planning Commission has moved to exercise other powers which will yicld the same result: increased bulk in the buildings which were originally to have been the transferees of unused development rights.

The Commission's most recent proposal was presented at a public hearing on a developer's plans to replace Tudor City Park, two small, private oases on 42nd Strect near First Avenue, with two new luxury apartment towers. Among the several zoning amendments drafted by the Commission staff to effect a compromise between the builder's goals and the local residents' desires was one proposing the establishment of Special Park Districts, within which the unused development rights of privately owned open spaces might be transferred to lots within the central business district. 
In defeating the Commission's amendment, the upper East Side residents cast grave doubt upon the master plan's rosy portrait of the "high level of services and transportation access" and other amenities claimed to be available for their neighborhood. Their arguments were presented by William Diamond, a former Housing Commissioner in the Lindsay administration, who now chaired Community Planning Board 8, the city's citizens' advisory panel responsible for the upper East Side. ${ }^{13 T}$

First, transfer of development rights to avenue-front apartments would increase the actual population density of the area, and thus the burden on district services and amenities, even though the permissible density under FAR ceilings remained constant. While the upper East Side's population had grown by over 15,000 since 1960 , there had been no increase in the amount of public open space for community residents. ${ }^{138}$ The overcrowding on the district's one subway line was notorious; ${ }^{139}$ and the automobiles of the new residents would add not only to the congestion in the streets but also to the pollution in the air. ${ }^{140}$ Moreover, the huge new buildings would themselves

The transferee lots could be used for either residential or commercial purposes, and would be limited to a ten per cent overage on the normal FAR; the future use of the transferor lots would be limited to "park-related passive recreation for the general public." The specific purpose of the proposal is to "promote the most desirable use of land in this area and thus to conserve the value of land and thereby protect the City's tax revenues." New York City Planning Commission, Rep. CP-22128, in Calendar of the City Planning Commission of the City of New York, Oct. 4, 1972, at 7. At the hearing the Commission reached no decision on the matter. See Clines, Planning Unit Approves Forest Hills Compromise, N.Y. Times, Oct. 5, 1972, at 51, col. 1.

137. Community Planning Boards, set up officially under the new City Charter, operate at a local but not necessarily a neighborhood Icrel. Sce NEw Yon: Cm l'Livning Commission, $C / P / D /$ : Community Plannisg Districts, Boundanies asd ProCEDUREs for MODIfICATION (1968). There are twelve such boards in Manhattan, sixty in the city as a whole. Each board has fifty members. Its effectiveness is dependent on the care with which the Borough President names members, the degree of consideration he gives board recommendations, and the spirit on the board itsclf.

138. Testimony of William J. Diamond, supra note 129 , at 5 .

139. In 1951 the voters approved a $\$ 500$ million bond issue which they beliened would finance a new subway under Second Avenuc. Under a litule-noted clause in the law, the money was instead utilized for urgently needed rehabilitation of signal systems and rolling stock on existing lines. The voters authorized $\$ 25$ billion in state borrowing for improved transportation once more in 1967. See Ascher, supra note 98, at 23. In 1969, the master planners were still counting on "the projected Sceond Avenue subway" which would "greatly improve access to east midtown, the lower east side, and downtown, and by doing so take the pressure off the now badly arercrowded Lexington Avenue line." Critical Issues, supra note 66, at 16. In October 1972, ground was finally broken for the first part of the Second Avenue line, which is to be completed in the fall of 1975 . This segment is north of the areas for which development rights transfer devices have been proposed. There is no firm estimate of completion date for the southern portion of the line. See N.Y. Times, Oct. 28, 1972, at 35 , col. 4.

140. Residents of the East Side call their district "asthma alley" because it has the highest rate of air pollution of any area in the city. Testimony of W'illiam $\mathrm{J}$. Diamond, supra note 129 , at 5 .

Recently, City officials conceded that one of the metropolis' key air pollutants-sus- 
increase that pollution through their heating, cooling, power generation, and refuse disposal. ${ }^{141}$

Secondly, the amendment, by allowing a developer to buy any side street property "for which it is found that continued preservation and maintenance would have been or would be unfeasible or unsafe,"142 might encourage owners on side blocks to permit their dwellings to deteriorate. "We would have introduced a new element, deterioration for profit, into the already sad decline of livable housing in this city," Diamond later declared. ${ }^{143}$ The absorption of the development rights of these demolished buildings by luxury high-rises would also change the character of the neighborhoods by driving away the middle class, unable to afford the new rents. ${ }^{144}$

Finally, those midblock wells of light which the city plan had vowed to preserve ${ }^{145}$ were again threatened. Apartment buildings in the R-10 zones along the avenues, generally limited to thirty stories, might go as high as forty-two under the amended rights transfer scheme.140

pended particulate matter, or dirt-had increased scven per cent over the past threc years despite stepped-up control efforts. Bird, City Air Found 7\% Dirtier Than in '69, N.Y. Times, Feb. 9, 1972, at 20, col. 4 .

141. In hearings on the selective rezoning discussed at note 128 supra, see also IN. FILL ZoNING, supra note 131, at 38-40, Board 8 Chairman Diamond substantiated this charge by making public a letter, part of which reads:

I believe an unfortunate and environmentally unacceptable preccdent is bcing set by the rezoning of the fifteen $R \cdot 8$ areas in Manhattan to higher density R.10.

It is clear to us now that, unless we change our strategy, there will be areas of the City in which we will be unable to meet the Federally mandated 1975 air pollution standards for stationary type pollutants-sulfur dioxide and particulates.

The areas likely to not meet standards include... castern and northern Manhattan. Thus, the City should not increase the pollution burden in these arcas by increasing housing density nor should it promote more people moving into these unhealthy areas rather than to less polluted areas of the city.

... We should gain concessions from the [builder] as to his methods of heating, cooling, power generation and refuse disposal.

...

The impact of 700 additional housing units on the castern Manhattan air pol. lution problem is small to be sure, but the precedent is troubling.

Letter from Fred C. Hart, Acting Commissioner of the New York City Department of Air Resources, to Donald Elliot, Chairman of the New York City Planning Commission, Jan. 31, 1972, on file at Yale Law Journal.

Obviously, development rights transfer on the scale to be encouraged by proposed amendment 74-89 would have involved many more than the 700 units which aroused the Department of Air Resources' concern here.

142. New York City Planning Commission, supra note 126, at 7 .

143. Knowles, supra note 128 , at 32 , col. 5 .

144. [The neighborhood groups] fought it primarily to avoid relocation. They predicted that the proposal would generate the formation of assemblages of sites and result in ultimate elimination of ethnic and economic diversity from the old rent-controlled structures. This controversy has underscored the likellhood that a broadened air rights transfer provision, if applied to old rent-controlled housing, would cause relocation and social exclusivity.

Marcus, supra note 4 , at 378 . East Side residents repeated these arguments in combatting the Planning Commission's proposal to rezone selected sites a year later. Sec N.Y. Times, Feb. 13, 1972, at 50, col. 1 .

145. See p. 363 supra.

146. Knowles, supra note 127. 
Ironically, forty-two stories was precisely the height of the old Equitable Building which had darkened the streets of the financial district and helped provoke New York's first zoning resolution so many years before. ${ }^{147}$

The Commission had declared that its proposed amendment had two objectives: to stop further redevelopment of the midblocks by keeping them at their present scale, and to increase the potential number of dwelling units in new buildings on the avenue. ${ }^{148}$ At the press conference announcing the proposal, preservation was emphasized as the primary aim. ${ }^{149}$ But one year later, following the defeat of this amendment, the planners were proposing a temporary FAR bonus for upper East Side sites zoned partially R-8, partially R-10, 150 which suggests that their first priority was indeed construction. Again, development rights transfer had been good camouflage for an exercise in fiscal zoning. The only opponents of the plan were the people who would have had to live with the results.

\section{The Impact of Development Rights Transfer}

\section{A. A Solitary Success-Perhaps}

With all the sound and fury generated by the rights transfer amendments since 1968, it might be thought that several builders would have rushed to take advantage of them and thereby contributed to the preservation of several New York landmarks. In reality, only one such transfer has been completely processed by the Commission, and it has yet to be consummated by construction of the new office building which is to absorb the landmark's development rights. This transaction demonstrates both the unreliability of development rights transfer as a preservation device and the folly of employing the technique without regard to the impact on existing facilities.

Amster Yard is a designated landmark group of nineteenth-century, one- to four-story brick residences built around a garden courtyard. Its lot between East 49th and 50th Streets had several thousand square

147. See note 1 supra and accompanying text.

148. Marcus, supra note 4 , at 378 .

149. Weisman, supra note 128:

The principle of transferring air rights has been used before, mostly to allow owners of landmarks ... to sell the rights over their structures as a compensation for not being able to demolish them.

Yesterday's proposal, however, was said to be the first time the principle was suggested to preserve the quality of a whole neighborhood.

150. See INFIL ZoNiNG, supra note 131, at 38-40; N.Y. Times, Feb. 13, 1972, at 50, col. 1 . 
feet of unused development rights. The owner of the adjacent lot proposed to build a forty-story office tower. The permitted zoning envelope for the tower allowed the development of 544,122 squarc feet. By purchasing an additional 30,967 square feet in development rights from Amster Yard, the developer could build two stories above the normal limit of forty. Alternatively, he could build larger, more desirable tower floors averaging 14,000 instead of 12,000 square feeta distinct commercial advantage worth at least a $\$ 30,000$ a year additional profit. ${ }^{151}$

In exchange, the developer made a number of design concessions, including the use of materials and colors sympathetic to the scale and style of the landmark and a covered shopping arcade on three sides of the new structure. The landmark owner or his trustee administrntor were to be paid $\$ 494,731$ over fifteen years for the transferred rights. Of that sum, $\$ 100,000$ was to be put in trust for the landmark's maintenance. ${ }^{152}$

"Although processed and tied with a ribbon"153 since the summer of 1970, the Amster Yard transfer has never been used because the market for new office space in New York is currently quite weak.154 An estimated fourteen million square feet of office space has been added to the market by buildings completed between 1970 and 1972 . The Planning Commission has estimated that in 1973 as much as thirty-four million of a total of 225 million square feet will go unrented. Only 2,904,000 square feet of new office space was rented in 1971 -the lowest amount in the last decade. ${ }^{155}$

151. Conti, supra note 4, at 15, col. 5; Huxtable, City Landmark Gets A Chance For Survival, N.Y. Times, Aug. 2, 1970, § 8, at 1, col. 1 .

152. Huxtable, supra note 151 .

153. Address by Norman Marcus, supra note 79 , at 9 .

154. Marcus, supra note 4 , at 376 . Professor Costonis notes this as the reason for the delay of the Amster Yard Transfer. Costonis, supra note 4, at 578 n.16. However, in his indictment of the inefficiency of the "New York plan" for preserving landmarks through development rights transfer, $i d$. at $586-89$, he never mentions the factor on which development rights transfer in any city must depend: the metropolitan market for new office building space or high density residential developments. The market is, in turn, the product of a combination of factors, including the costs of land, labor, and moncy; and no mere loosening of the "straightjacket of administrative controls" in Ncw York, in favor of the arguably more flexible "Chicago plan," is going to remove the market impediment to landmark preservation through development rights transfer.

The market for commercial space is currently severely depressed in several major citics, including Chicago (with a vacancy rate of over ten per cent and ten million more square feet of office space coming on the market by 1975), Boston (vacancy over eight per cent), Pittsburgh (over twenty-five per cent), Dallas (over twenty-five per cent), Houston, San Francisco, Los Angeles, Atlanta, St. Louis and Minneapolis. See articles by Horsley, Oser, and Brown, supra note 123. And of course, once this excess base is absorbed, the construction of new buildings incorporating landmark development rights can only mcan increasing the density levels of these downtown areas.

155. Horsley, supra note 123. This oversupply has its roots in the fevered rental market of the late 1960's. From the mid-1940's through 1966, rental rates for new space in prime locations moved upward slowly, from $\$ 4.50$ per square foot to $\$ 6.50$. 
Thus, the initial defect in any program designed to preserve landmarks through development rights transfer is that it cannot work unless a builder wants those development rights, regardless of the distance he can transfer them. ${ }^{150}$ An eminently more reliable method of landmark preservation was and is available under the city's Landmarks Preservation Law, ${ }^{157}$ and that legislation should continue to save more architectural monuments than development rights transfer schemes ever will.

The second flaw in the landmarks version of the device is that any rights transferred are most likely to flow to areas which are already highly congested due to those private economic advantages of concentration which make transfer attractive in the first place. ${ }^{138}$

The proposed office tower adjacent to Amster Yard has a prime location, and so development rights transfer making possible two extra floors would be profitable for the builder. But the structure will bring about 3600 more workers into the Grand Central area, ${ }^{130}$ where the present strain on surface and subway transportation is already intolerable according to both the master planners and those who travel there. About 200 of those workers will occupy the floor space transferred from Amster Yard. That is, to be sure, a small number compared with the 2000 who would be brought in by the exploitation of the unused development rights of the U.S. Custom House. ${ }^{160}$ But in either case, given the sorry state of mass transit in

But in 1968 rates jumped to $\$ 8.50$, and by 1969 , rentals for 1971 occupancy were going for $\$ 10$ per square foot. This rise in rentals was due to the shortage of space brought about by the rise in employment, which began to move up in 1965 much faster than before. See Carruth, Manhattan's Office Building Binge, Fosruse, Oct. 1969, at 114,115 .

Where in 1968, some 4,980,000 square feet of office space came on the market, 1969 produced 11,980,000 square feet, 1970 added another $8,651,000$, and the city-wide construction completion figure for 1971 was $14,869,000$ square feet-the largest figure for any year in the postwar era. The city's rate of absorption of office space, which reached a peak of 9.9 million square feet in 1969, did not keep pace with this mie of development, and in 1970 only 6.2 million square feet were leased. Horsley, supra note 123 .

156. This objection applies not only to Section 74-79 as amended, but also to Pro. fessor Costonis" "development rights transfer districts," which would be those areas where landmarks are concentrated. See Costonis, supra notc 4, at 590.

157. See pp. 350-51 supra.

158. See p. 342 supra.

159. The Planning Commission has "nothing so neat as a table of conversion" for translating floor space into number of employees, but rather fecls the figures in the 1961 zoning study are still "useful as rules of thumb." Letter from Norman Marcis, supra note 54. That study shows an average of 157 square lect per office vorker in 1955 with a projected trend upwards to 190 square feet per office worker in 1975. ZoNiNG NEw YoRK CITY, supra note 42 , at 11 . The number of workers given in the text was calculated using the 157 square feet per emplojec figure.

160. See p. 360 supra, on the Custom House transfer, which was never consummated, and Dissenting Report of Commissioner Beverly Moss Spatt, supra note 120, at 3282, for the number of new office workers which its unused development rights represent. 
New York and all the attendant ills to which a densely-developed city is heir, the wisdom of encouraging an increase in congestion through development rights transfer is at best doubtful.

\section{B. The Larger Failure}

The development rights transfer technique has not proven helpful in preserving landmarks in New York, and its utilization in a residential context was seen by the citizens affected as a threat to the character and viability of their midblock neighborhoods. Almost assuredly, in order to spur construction and generate increased tax revenues, the Planning Commission will formulate other versions of the device. The city's Real Estate Commissioner has proposed widespread transfer of development rights from municipal fire houses, police stations, and schools, both to adjacent sites and to properties farther away. The Planning Commission has yet to permit this, but the siren song of growth may prove irresistible.

But certain conclusions from New York's experience with the technique are already clear, and these are worth pondering by any city contemplating its adoption. First, development rights transfer is not a necessary device for saving landmarks, where the municipal landmarks commission has other preservation powers and is willing to employ them. ${ }^{101}$ Second, it is not a reliable device for landmark preservation, because it depends on the local market for new office

161. A wide variety of preservation devices has been developed. See, e.g., R. MontacuE \& T. Wrenn, Planning for Preservation (Am. Soc'y of Planning Officials 1964); J. Morrison, Historic Preservation (2d ed. 1965); Wolfe, Conservalion of Historic Buildings and Arcas-Legal Techniques, in 2 ABA Section on ReAl Pror., Pronstre \& Trust Law, Proceedings at 18 (1963); Turnbull, Aesthetic Zoning, 7 WaKe Foresr $\mathrm{L}$. REv. 230 (1971); Comment, Legal Methods of Historic Preservation, 19 Buffalo $L$. REv. 611 (1970); Note, The Police Power, Eminent Domain and the Preservation of Historic Property, 63 Colum. L. Rev. 708 (1963); Comment, Aesthetic Zoning: Preserva. tion of Historic Areas, 29 Fordham L. Rev. 729 (1961); Special Issue, Histaric Preserva. tion, 36 Law \& Contemp. Prob. $309-444$ (1971); Comment, Landmark Preseruation Laws: Compensation for Temporary Taking, 35 U. CHI. L. REv. 362 (1968).

It has been argued that the New York City Landmarks Preservation Law, discussed at pp. 350.51 supra, "enables the city's Landmark Commission to cxert considerably greater leverage in dealing with landmark owners than commissions in other citles enjoy." Costonis, supra note 4 , at $581-82$ n.30. However well-founded, this observa. tion is no argument for the adoption of a zoning device such as development rights transfer if its employment compounds the congestion, pollution, and gencral aggravation of living and working in the central city.

Although the National Trust for Historic Preservation does not maintain a list of those cities permitting development rights transfer from landmarks, a scarch of the Trust's legal archives revealed no cities which authorized transfer other than San Francisco and New York. Letter from Roger Holt, Assistant for Legal Scrvices, Dcpartment of Field Services, National Trust for Historic Preservation, to author, Mar. 10, 1972, on file at Yale Law Journal. San Francisco's law permits the transfer of a landmark's total unused development rights to adjacent parcels. SAN Francisco, Calif., Planning Code $\$ 122.4(\mathrm{~b})$. But a published discussion of this provision docs not reveal how often it has been used. Svirsky, San Francisco: The Downtown De. velopment Bonus System, in THE NEW ZoNiNG, supra note 56, at 139, 152. 
space. This market may well be glutted through overbuilding or, ironically, through the extensive utilization of other FAR bonus provisions in the municipal zoning ordinance. ${ }^{102}$ Third, it is not even a serviceable device over the long run, unless the city intends to abandon effective limits on the intensity of development. Only new and bigger office towers and apartments can absorb the transferred rights, and this necessarily means increased residential and employee densities. ${ }^{103}$

Finally, development rights transfer is a pernicious device in today's congested cities. Whether from landmarks, midblock brownstones, or municipal buildings, unused rights will always flow to those areas where the commercial advantages of concentration make transfer economically attractive. If this existing concentration is attended by its usual effects-if the subways and buses are overloaded; the streets, clogged; the air, polluted; and the few remaining open spaces, in the perpetual shadow of surrounding office or apartment towers-then development rights transfer can only make life more miserable.

In the final analysis, debate on the merits of development rights transfer is really an argument about the optimal size of buildings in the central city. Forty years ago, one commentator cast the controversy in such terms:

Conclusive quantitative proof of the desirability of these things [sunlight, air, etc.] is almost impossible, as is also the setting up of any unqualified standard for safety and well-being below which

162. On the depressed market for office space in several major cities, see note $15 t$ supra. It seems likely that part of this unrentable floor space may have been developed through other FAR bonus devices, so that the bonus technique and the development rights transfer technique work at cross-purposes. Indeed, this seems to have been precisely the result in New York. See note 155 supra. For a comprchensive survey of the numerous bonus incentive zoning techniques emplojed in several major American cities, see M. Brooks, Bonus Provisions in Cextral Cits Areas (Am. Soc'y of Planning Officials, Planning Advisory Service Report No. 257, 1970).

163. In the first published version of what became the "Chicago Plan," Professor Costonis wrote of "the problem of super-density":

.Transfers under the proposal must be carefully meshed with the municipality's planning and zoning standards. Prevailing bulk limitations reflect or, at least, should reflect a careful assessment of the city's space needs and the capacity of its public services to handle the demands of the projected densities. Addition or rearrangement of bulk threatens to upset this assessment ....

Transfers should be permitted only within the highest density commercial and residential zoning districts. Public services and facilities are most plentiful in these districts and will not suffer overloads from the margindl densily increases resulting from the program.

J. Costonis \& J. Shlaes, Development Rights Transfers: A Solution to Chicago's Landmarks Dilemma 7, May 13, 1971 (Chicago Chapter Foundation of the American In. stitute of Architects National Trust for Historic Preservation) (cmphasis added). Ccrtainly Costonis and Shlaes are correct in asserting that bulk limitations should reflect an intelligent assessment of a municipality's needs for space and services. But their claim that such facilities are most plentiful "within the highest density commereinl and residential zoning districts" is simply not true in New York, and remajus unsubstantiated with regard to other major American cities in either the jointly-authored study or the later Costonis article. 
we should not go. The general indications would lead to the belief that, while sunlight, air, outlook, privacy, the avoidance of a sense of "shut-in-ness" and of actual congestion are highly desirable, we are not able to set up a minimum which, let us say, if curtailed by 10 percent would spell disaster or if augmented by 10 percent would spell relative happiness and prosperity. ${ }^{104}$

Because conclusive proof is still lacking, proponents of transfer schemes can argue with some conviction that this new zoning prac. tice "is defensible in planning terms." 105 But whatever the planning terms, the results of urban concentration are increasingly intolerable in human terms, and a zoning device aimed at increasing that concentration deserves censure rather than praise.

In sum, development rights transfer will be justified only where planning administrators condition its use on the establishment of open space and services which adequately satisfy the needs of the existing population. And even if the planners can meet such conditions, they should still consider the critique of New York's "new zoning" made by an administrator of the New York State Office of Planning Services:

The one philosophical point implicit in the 1961 Resolution is that the attainment of zoned capacity is undesirable, unnecessary and unwarranted. The envelope that was created was to provide some reasonable expectation of flexibility within the framework of planning considerations. The idea of every parcel being developed to its maximum either directly or through transfer of development rights, while becoming increasingly popular as a sophisticated expression of laissez-faire, is essentially a perversion of all that planning has traditionally stood for. The major thrust behind much of the new incentive zoning is growth, albeit related to economics. Growth, too, is the major characteristic of cancer. ${ }^{106}$

164. Randall, The Question of Size: A Re-Approach to the Study of Zoning, 54 ARCH. FORUM 117 (1931).

165. Costonis, supra note 4 , at 629-30. This same attitude is apparent in a recent publication of the Department of City Planning in New York:

The changes in bulk called for in our proposals would still kecp the arcas in. volved well within the theoretical zoned capacity of the 1961 Zoning Resolution, and many lots affected would only be built with the number of units originally envisioned because they would merely be exempted from stringent technical regula. tions which had precluded development. Thus, the intent of the 1961 zoning in matching density with existing and planned facilities would be followed.

INFIL. ZoNinG, supra note 131, at 9.

Yet when these proposed changes in bulk were announced, thcy provoked great op. position in the affected neighborhoods precisely because current poptulation densitics had not been matched "with existing and planned facilities." See N.Y. Timcs, Feb. 13,1972 , at 50 , col. 1 .

166. Letter from Edwin Friedman, supra note 42. 